\title{
Use of Information Communication Technologies (ICTs) among Researchers, Extension Workers and Farmers in Abia and Enugu States: Implications for a National Agricultural Extension Policy on ICTs
}

\author{
Agwu A. E; U. C. Uche-Mba and O. M. Akinnagbe \\ Department of Agricultural Extension, \\ University of Nigeria, Nsukka, Enugu State, Nigeria. \\ E-mails: agwuekwe@hotmail.com; ulumbah@yahoo.com; wolexakins@yahoo.com
}

\begin{abstract}
The study ascertained the level of usage as well as constraints to the use of information communication technologies (ICTs) among major stakeholders in the agricultural development process in Abia and Enugu States of Nigeria. Data for the study were generated from a sample of 110 respondents using structured interview schedule and questionnaire. Findings indicate that majority $(52.5 \%, 57.5 \%$ and $56.7 \%)$ of researchers; extension workers and farmers had high, moderate and low knowledge levels of available ICTs, respectively. Out of 24 information communication technologies in use among the respondents, 11 were frequently utilized by researchers, while only 4 and 3 of the facilities were frequently utilized by extension workers and farmers, respectively. The study revealed major constraints to the use of ICTs to include lack of sufficiently trained computer personnel, lack of confidence in operating modern ICTs, erratic and fluctuating power supply, poor finance, lack of internet access in the rural areas and high cost of ICTs hard and soft wares, among others. The study concludes with the need to have a National Agricultural Extension Policy on the use of ICTs with major emphasis on access, availability and use.
\end{abstract}

Key words: Information communication technologies, knowledge, access, constraints, policy needs.

\subsection{Introduction}

There is scarcely a field of human activity today that has not been touched by the dramatic changes in Information and Communication Technologies (ICTs) that have taken place in the last 10-15 years. The Academy for Educational Development and Win rock International (2003) defines information and communication technologies as the combination of hardware, software, and the means of production that enable the exchange, processing, and management of information and knowledge. Information communication technologies thus include technologies and methods for storing, managing, and processing information (e.g., computers, soft wares, digital and nondigital libraries) and for communicating information such as mail and email, radio and television, telephones, cell phones, pagers, instant messaging and "the web." However, in everyday speech, ICTs commonly refer to electronic and digital devices and the software used for storing, retrieving, and communicating information. 
Information Communication Technologies have unique features that provide opportunities to harness them in ways that are different from how the traditional media have been used for development. According to Michiels and Van Crowder (2001), in comparison with traditional media, ICTs can offer opportunities for two-way and horizontal communication and for opening up new communication channels for rural communities and the intermediaries and development organizations that support them. Once mastered, they potentially allow every user to be a sender, receiver, 'narrowcaster' and broadcaster; support bottom-up articulation of development needs and perceptions, and facilitate the merging of global and local knowledge and information, support, create and strengthen interactive and collaborative networks that enable information to flow to and from rural communities; facilitate dialogue between communities, intermediaries and development organizations; foster coordination of national and local development efforts; and overcome physical barriers to knowledge and information sharing. ICTs can also enhance the capacity of grassroots organizations to make their voices heard. ICTs improve the ability to search for information and increase the quantity of information available, ultimately reducing uncertainty and enhancing market participation. Answers to question such as "how do buyers and sellers find each other and what price can be achieved?" and "is it better to store the produce or sell it immediately?" can be easily achieved through the use of ICTs (Bertolini, 2004). ICTs also present new opportunities for individuals and communities to be not only consumers but also producers of information.

According to CTA (2000) efficient information dissemination remains the key to bridge the gap between developed and underdeveloped countries. This is the challenge that confronts development actors and stakeholders in developing countries. Information and the technologies that facilitate its use, exchange, and reliability have been important aspects of agriculture and agriculture-related natural resource management for centuries. Decisions on what to plant, when to plant it, how to cultivate and harvest, and where to store and sell and at what price to sell, have long depended on knowledge, communication, and information exchange.

Agricultural extension, which depends to a large extent on information exchange between and among farmers on the one hand, and a broad range of other actors on the other, has been identified as one area in which ICTs can have a particularly significant impact. There is growing recognition that farmers and members of rural communities have needs for information and appropriate learning methods that are not being met (Greenridge, 2003; Lightfoot, 2003), and these have been lacking in Nigeria. In the midst of this change, extensionists are grappling with the question of how best to harness information and communication technologies (ICTs) to improve rural livelihoods. Meera et al (2004) had noted that as a result of the emerging new paradigm of agricultural development, old ways of delivering important services to citizens are being challenged; traditional societies are also being transformed into knowledge societies all over the world

Studies have shown that agricultural development in Nigeria and other African countries have been hampered by low level of agricultural information exchange. Arokoyo (2003) reported that in Nigeria, the national extension service is based on the T\&V delivery system, traditionally supported by mobile cinema, video, television, radio and telephone being the only ICT used by majority of extension workers. However telephone use in extension delivery even with the launch and explosion of the global system of mobile communication (GSM) is very limited as most ADPS even at the headquarters do not have functional lines (Agwu and Chah, 2007). The serious 
limitation of access to reliable telephone line makes even ordinary intra and inter organization networking for information exchange a harrowing and frustrating experience. The vision of the public agricultural extension system in Nigeria is that there should be a media sub-unit within agricultural sub programmes equipped with modern communication facilities for effective communication both within the organization and to link research institutes, related agencies and farmers. Therefore, this study focused on assessing the level of usage as well as constraints to the use of ICTs among researchers, extension workers and farmers in Abia and Enugu states of Nigeria.

\section{Objectives of the Study}

The broad objective of this study was to ascertain the level of usage as well as constraints to the use of information communication technologies (ICTs) among major stakeholders in the agricultural development process in Abia and Enugu States of Nigeria. The specific objectives were to:

1. ascertain the knowledge, awareness and access to information communication technologies among researchers, extension workers and farmers;

2. identify the available ICT facilities and their frequency of usage; and

3. determine the constraints to the use of ICTs in agricultural development process as perceived by the researchers, extension workers and farmers.

\subsection{METHODOLOGY}

\section{The study area}

This study was carried out in Enugu and Abia states of Nigeria. The two states are in the South East agro ecological Zone of the country. The Zone lies between latitudes $4^{0}-7^{0} \mathrm{~N}$ and spreads over a total of $78,612 \mathrm{~km}^{2}$ representing $8.5 \%$ of the country's total land area (Shaib et. al., 1997). It is the most thickly populated zone in the country with a population of 18.9 million (1991 Census) and a density of 241 persons $/ \mathrm{km}^{2}$, with rural population constituting $60 \%$ of the total. The climate is typically equatorial with distinct dry and rainy seasons. The mean annual rainfall varies from $1500 \mathrm{~mm}$ in the northern fringes of Cross River, Enugu and Anambra States to over $3000 \mathrm{~mm}$ in the costal areas. Three distinct vegetation types found in the zone are the humid forest, derived savanna and semi montane. The zone is predominantly agricultural with yam, cassava, palm produce and rice being its main products.

\section{Population / Sampling procedure}

The target population for this study include researchers (from the National Root Crops Research Institute (NRCRI), Umudike and University of Nigeria, Nsukka) as well as the public extension workers and farmers in Enugu and Abia states. Simple random sampling procedure was used to select 20 researchers each, from the National Root Crops Research Institute, Umudike and Faculty of Agriculture, University of Nigeria. Also, 20 extension workers were randomly selected from each of the public extension organization (Agricultural Development Programme (ADP)) in each of the state. Again, 20 randomly selected farmers from each of the state also participated in the study. In all a total of 120 respondents participated in the study. 
Journal of Agricultural Extension

Vol. 12 (1) June, 2008

\section{Data collection/ Measurement of variables}

Data were collected through the use of questionnaire. Objective one was achieved by asking respondents questions relating to their knowledge and awareness level on the role of ICTs in agricultural development. Ten questions were asked and a maximum of 1 point was awarded for a correct answer to each question and 0 point for a wrong answer.

The respondents were categorized into 3 groups based on their knowledge level namely:

a. Low knowledge (for those with 1-3 points)

b. Moderate knowledge (for those with $4-7$ points) and

c. High knowledge (for those with 8-10 points)

Objective 2 was achieved by asking respondents to indicate their frequency of usage of available ICTs, e.g. computer, internet and cell phone. A three-point Likerttype scale with responses ranging from "never used" to "very often used" and scaled 1 to 3 respectively, was utilized. Objective 3 was achieved by listing 20 possible constraints to the use of ICTs in agricultural development and asking respondents to rate the level of seriousness of these constraints. A 3-point Likert type scale of "very serious", "serious" and "not serious at all" were used to measure their responses. Responses of the three-point scales were later categorized according to their mean scores. In terms of frequency of usage of available ICTs, mean scores of 2.00 or above were classified as frequently used, while in terms of constraints to the use of ICTs in agriculture, variables with mean scores of 2 and above were regarded as serious constraints to the use of ICTs in agriculture, and variables with mean scores below 2 were regarded as minor constraints. Mean scores and percentages were used to analyze all the data.

\subsection{RESULTS AND DISCUSSION}

\section{Some Selected Characteristics of the Respondents}

\section{Gender}

Table 1 shows that majority $(67.5 \%)$ of the researchers were males while the remaining $32.5 \%$ were females. Also, $70.0 \%$ of the extension workers were males while $30.0 \%$ were females. In the same vein, $66.7 \%$ of the farmers were males while $33.3 \%$ were females. This implies that the researchers and extension workers were predominantly males. This may be connected with the gender disparity found in the public civil service in Nigeria. With the socio-cultural factors that restrict contact between gender in some communities (Arokoyo, Chikwendu, and Ogunbameru, 2002), appropriate use of ICTs in extension delivery could significantly reduce or eliminate such barriers.

\section{Age (years)}

Table 1 shows that $40.0 \%$ of the researchers were between 30 and 39 years, while $30.0 \%$ were within the age range of $40-49$ years. However, only $15.0 \%$ of research workers were between the age of 50 and 59 years. Table 1 also shows that $42.5 \%$ of the extension workers were within the age range of $30-39$ years, while $32.5 \%$ were 40 - 49 years. Only $20.0 \%$ of the extension workers were 30 years, while $5.0 \%$ of them were 50 - 59 years. The Table further shows that $36.7 \%$ of the farmers were between the age range of $40-49$, while $26.7 \%$ were within $30-39$ years old and $16.7 \%$ of them 
were between the age range of 50- 59. This indicates that the three groups of respondents were predominantly in their middle ages. This trend may have significant implication for ICTs usage since the elderly might be less interested in using hi-tech communication devices and prefer oral to printed information channels which are less efficient (Agwu and Chah, 2007).

\section{Educational qualification}

Table 1 further indicates that $37.5 \%$ of the researchers had masters degree, $27.5 \%$ and $22.5 \%$ had $\mathrm{PhD}$ and BSc degrees respectively, while the remaining $7.5 \%$ and $5.0 \%$ had HND and OND, respectively. On the part of the extension workers $35.0 \%$ had HND certificates while $32.5 \%$ had BSc. Also, 22.5\% had MSc degrees while the remaining $10.0 \%$ had OND. This indicates that they can harness information and communication technologies (ICTs) to improve rural livelihoods. On the other hand, a greater proportion $33.3 \%$ of the farmers had SSCE, while $16.7 \%$ had BSc. Also, $16.7 \%$ had first school leaving certificates, while $13.3 \%$ and $6.7 \%$ had OND and M.Sc certificates, respectively. Only about $13.3 \%$ had Teachers Grade II Certificate. This findings show that a majority of those involved in farming activities were not graduates and may not fully appreciate the role of information communication technologies in the improvement of agriculture.

TABLE 1: Percentage distribution of respondents by some selected characteristics

\begin{tabular}{lccc}
\hline $\begin{array}{l}\text { Socio-economic } \\
\text { characteristics }\end{array}$ & $\begin{array}{c}\text { Researchers } \\
\%\end{array}$ & $\begin{array}{c}\text { Extension } \\
\text { workers \% }\end{array}$ & Farmers \% \\
\hline Sex & 67.5 & 70.0 & 66.7 \\
Male & 32.5 & 30.0 & 33.3 \\
Female & & & \\
Age & 12.5 & 5.0 & 6.6 \\
Below 30 years & 40.0 & 42.5 & 26.7 \\
30-39 & 30.0 & 32.5 & 36.7 \\
$40-49$ & 15.0 & 20.0 & 13.3 \\
$50-59$ & 2.5 & - & 16.7 \\
60 and above & - & - & 16.7 \\
Educational qualification & - & - & 33.3 \\
First school leaving certificate & - & - & 13.3 \\
Teachers grade II certificate & 5.0 & 10.0 & 16.7 \\
SSCE & 7.5 & 35.0 & 6.7 \\
OND & 22.5 & 32.5 & 13.3 \\
HND & 37.5 & 22.5 & - \\
BSC & 27.5 & - & - \\
MSC & & & \\
Ph D & & & \\
\hline
\end{tabular}


Journal of Agricultural Extension

Vol. 12 (1) June, 2008

\section{Respondents' level of knowledge, awareness and access to ICT facilities}

Table 2 shows the respondents' knowledge level of ICTs. A majority (52.5\%) of the researchers had high knowledge level while only $7.5 \%$ had low knowledge level of ICTs. In the case of the extension workers, majority $57.5 \%$ had moderate knowledge level while only $10.0 \%$ had low knowledge level. On the part of farmers, majority $(56.7 \%)$ had low knowledge level of ICTs. This shows that apart from the researchers, the extension workers and farmers need to be trained on the use of ICTs.

Table 2 also shows that majority $(72 \%)$ of the researchers and extension workers $(63 \%)$ had high level of awareness of the major ICT tools, while only $41 \%$ of the farmers interviewed were highly aware of these tools. It is important to recognize that awareness among policy makers on the potentials of ICTs is a critical element for its development. The Table also shows that $65 \%$ of the researchers, $56 \%$ of the extension workers and $33 \%$ of the farmers asserted that they had access to ICT facilities. The fact that majority $(67 \%)$ of the farmers do not have access shows that most rural areas in Enugu and Abia states don't have access to major ICT facilities and so are not likely to be aware of major agricultural findings. According to UNDP (2001) the problem of underdevelopment is attributable to the inability of a large portion of the world's population to access and effectively use ICTs.

TABLE 2: Distribution of respondents by their knowledge, awareness and access levels of ICTs

\begin{tabular}{lccc}
\hline Variables & Researchers \% & $\begin{array}{c}\text { Extension Workers } \\
\%\end{array}$ & Farmers \% \\
\hline Knowledge Level & 52.5 & 32.5 & 16.7 \\
High knowledge & 40.0 & 57.5 & 26.7 \\
Moderate knowledge & 7.5 & 10.0 & 56.7 \\
Low knowledge & & & \\
Awareness level & 72 & 63 & 41 \\
High awareness & 28 & 37 & 59 \\
Not aware & & & 33 \\
Access Level & 65 & 56 & 67 \\
Access & 35 & 44 & \\
Limited access & & & \\
\hline
\end{tabular}

\section{Use of Information Communication Technologies among Respondents}

Data on Table 3 show that out of 24 ICT facilities listed, 14 facilities were frequently used by the researchers and these facilities include Internet $(\bar{x}=2.25)$, Television set $(\bar{x}=2.07)$, Voltage stabilizer $(\bar{x}=2.17)$, Radio set $(\bar{x}=2.25)$, Printer $(\bar{x}=2.02)$, Flash drive $(\bar{x}=2.10)$, Diskette $(\bar{x}=2.20)$, Computers $(\bar{x}=2.20)$, UPS $(\bar{x}=2.08)$, Mobile phone $(\bar{x}=2.58)$, and E-mail $(\bar{x}=2.30)$. 
On the part of the extension workers, only 4 out of the 24 facilities were frequently used by extension workers and these include Video player $(\bar{x}=2.00), \mathrm{T}$.V $(\bar{x}=2.10)$, Radio set $(\bar{x}=2.58)$ and Mobile phones $(\bar{x}=2.55)$, while the other ones were not frequently used. This shows a very low level of digital ICTs utilization by the extension workers, especially the computer facilities. Seepersad (2003) reported that cell phones are fairly common among extension employees but however added that cell phones have not been used in an organized way by agricultural organizations. Yekinni and Olaniyi (2007) also reported that majority of the research and extension personnel in Southwestern Nigeria never used video, CD-ROM technology, organizational e-mail, organizational website and personal website in their work schedule.

On the part of the farmers, only 3 facilities were used frequently and they include: T.V $(\bar{x}=2.20)$, Radio $(\bar{x}=2.57)$ and Mobile phones $(\bar{x}=2.03)$. This also shows a very low level of utilization of digital ICT facilities by farmers in the two states. This implies that a large majority of the extension personnel and farmers will not have access to many useful materials found in the internet. The internet is a formidable source of information on recent developments in the field of agricultural extension (Agwu and Chah, 2007). However such information can only be available to those who source for it. These findings generally indicate the low digital ICT-readiness of major stakeholders in the agricultural development process of the country and points to the need to entrench ICTs access, availability and use mandates into policies establishing the national extension system. 
Journal of Agricultural Extension

Vol. 12 (1) June, 2008

TABLE 3: Respondents' mean ratings on extent of use of ICT facilities in Enugu and Abia States

\begin{tabular}{lcccccc}
\hline ICT Facilities & \multicolumn{3}{c}{ Researchers } & \multicolumn{2}{c}{ Extension } & \multicolumn{2}{l}{ Farmers } \\
& & \multicolumn{3}{c}{ workers } \\
& $\bar{x}$ & SD & $\bar{x}$ & SD & $\bar{x}$ & SD \\
\hline Internet & 2.25 & 0.870 & 0.98 & 1.050 & 0.63 & 1.033 \\
Intranet & 0.65 & 0.893 & 0.05 & 0.221 & 0.10 & 0.548 \\
Video recorder & 0.77 & 1.050 & 1.82 & 1.023 & 0.83 & 1.085 \\
Video player & 1.48 & 1.062 & 2.00 & 1.013 & 1.57 & 1.278 \\
Slide projector & 0.75 & 0.670 & 0.73 & 0.877 & 0.13 & 0.346 \\
Film projector & 0.53 & 0.679 & 0.57 & 0.781 & 0.17 & 0.592 \\
Multi-media projector & 0.60 & 0.778 & 0.18 & 0.385 & 0.03 & 0.183 \\
Magnetic board & 0.93 & 1.185 & 0.45 & 0.639 & 0.13 & 0.346 \\
Television set & 2.07 & 1.163 & 2.10 & 1.150 & 2.20 & 1.064 \\
Camera & 1.28 & 1.062 & 1.40 & 1.128 & 0.90 & 1.213 \\
Voltage stabilizer & 2.17 & 1.107 & 1.70 & 1.203 & 1.38 & 1.399 \\
Radio set & 2.25 & 1.056 & 2.58 & 0.781 & 2.57 & 0.971 \\
Printing machine/ printer & 2.02 & 1.165 & 1.30 & 1.203 & 0.86 & 2.117 \\
Scanner & 1.08 & 0.917 & 0.33 & 0.656 & 0.37 & 0.890 \\
Flash drive & 2.10 & 1.033 & 0.60 & 0.900 & 0.43 & 1.006 \\
Diskette & 2.20 & 0.966 & 0.60 & 0.778 & 0.60 & 1.070 \\
Computers & 2.20 & 1.067 & 1.48 & 1.132 & 0.60 & 0.932 \\
CD-ROMs & 1.80 & 1.159 & 0.83 & 0.958 & 0.50 & 1.009 \\
DVD & 1.33 & 1.347 & 0.45 & 0.846 & 0.40 & 0.894 \\
Fixed telephone & 1.70 & 1.159 & 0.75 & 1.080 & 0.83 & 1.262 \\
Photocopier & 1.92 & 1.071 & 1.33 & 1.071 & 0.97 & 1.129 \\
Uninterrupted Power Supply & 2.08 & 1.095 & 1.00 & 1.109 & 0.93 & 1.230 \\
Mobile phone & 2.58 & 0.747 & 2.55 & 0.815 & 2.03 & 1.299 \\
E-mail & 2.30 & 0.966 & 1.45 & 1.239 & 1.27 & 1.285 \\
\hline
\end{tabular}

\section{Constraints to the use of ICTs in agriculture}

Data in Table 4 show that out of the twenty possible constraints listed in the study, eight were considered to be serious constraints to the use of ICTs in agriculture by researchers. These include lack of communication infrastructure on which ICTs depend $(\bar{x}=2.00)$, lack of sufficient trained computer personnel $(\bar{x}=2.03)$, erratic power supply $(\bar{x}=2.55)$, poor finance $(\bar{x}=2.32)$ and lack of internet access in the rural areas $(\bar{x}=2.60)$. Others include; poor communication network $(\bar{x}=2.10)$, high cost of ICTs soft ware $(\bar{x}=2.00)$ and high cost of ICTs hard ware $(\bar{x}=2.08)$. It is generally agreed that ICTs access unevenly favour urban and wealthy residents. Arokoyo (2003) had earlier observed that the adoption and utilization of ICTs in agriculture are constrained among other problems by inadequate infrastructure, limited human resource capacity, absence of national policies and low ICTs literacy.

On the part of the extension workers, twelve out of the 20 statements were considered as serious constraints to the use of ICTs. These specific constraints perceived by extension workers include; lack of competence in handling ICT facilities $(\bar{x}=2.30)$, unavailability of hard ware required by modern ICTs $(\bar{x}=2.00)$, erratic power supply $(\bar{x}=2.03)$ and lack of communication infrastructure on which ICTs depend $(\bar{x}=2.03)$. It is important to recognize that availability and affordability of 
telecommunications infrastructure and support for rural communities, researches and extension organizations is generally lacking in Nigeria. Specifically, the availability of equipment including phones (fixed and mobile), computers, radio, TV, video camera, a robust telecommunication system, preferably with reliable broad band with easy internet access and assured operation funds are not affordable by majority of stakeholders found in the agricultural sector, even when available. Other constraints include lack of sufficient trained computer personnel $(\bar{x}=2.00)$, poor finance $(\bar{x}=$ $2.48)$, lack of adequate awareness about ICTs $(\bar{x}=2.28)$, lack of internet access to the rural areas $(\bar{x}=2.45)$, poor communication network $(\bar{x}=2.23)$ and nature of information provided $(\bar{x}=2.30)$.

The farmers also considered 12 constraints as major constraints to the use of ICTs. These include lack of confidence in operating ICT facilities such as computers $(\bar{x}=2.40)$, lack of competence in handling ICT facilities $(\bar{x}=2.33)$, lack of adequate time for training on ICT facilities $(\bar{x}=2.33)$ and unavailability of hardware required for modern ICTs $(\bar{x}=2.23$. Others include; lack of communication infrastructure on which ICTs depend $(\bar{x}=2.20)$, lack of computer trained personnel $(\bar{x}=2.20)$ and erratic and fluctuating power supply $(\bar{x}=2.70)$. However, electricity and power supplies are absolute prerequisites to using contemporary ICT systems. Bertolini (2004) had earlier observed that several obstacles hinder ICTs usage in developing countries, especially in areas of access to telephone and electricity networks. According to the Academy for Educational Development and Win rock International (2003) over 1.5 billion people in developing countries lack relatively inexpensive grid or 'mains' electric service, and over a billion people will continue to lack grid electricity for the foreseeable future. For these people, other energy options such as small renewable energy-based power systems (solar photovoltaic (PV), small wind-electric turbines), are essential if they are to benefit from rural ICTs use. Other constrains include complexity in using ICTs $(\bar{x}=2.23)$, lack of internet access to the rural areas $(\bar{x}=2.00)$, nature of information provided $(\bar{x}=2.43)$, high cost of ICT software $(\bar{x}=$ 2.43), and high cost of ICTs hard ware. 
Journal of Agricultural Extension

Vol. 12 (1) June, 2008

TABLE 4: Mean scores of constraints that hinder the use of ICT in agriculture

\begin{tabular}{|c|c|c|c|}
\hline Constraints & $\begin{array}{l}\text { Researchers } \\
(\bar{x})\end{array}$ & $\begin{array}{c}\text { Extension } \\
\text { workers } \\
(\bar{x})\end{array}$ & $\begin{array}{l}\text { Farmers } \\
\qquad(\bar{x})\end{array}$ \\
\hline $\begin{array}{l}\text { Lack of confidence in operating ICT } \\
\text { facilities such as computers, CD Rom }\end{array}$ & 1.50 & 1.78 & $2.40^{*}$ \\
\hline $\begin{array}{l}\text { Lack of competence in handling ICT } \\
\text { facilities }\end{array}$ & 1.78 & $2.30^{*}$ & $2.33^{*}$ \\
\hline $\begin{array}{l}\text { Lack of adequate time for training on ICT } \\
\text { facilities }\end{array}$ & 1.60 & 1.90 & $2.33^{*}$ \\
\hline $\begin{array}{l}\text { Unavailability of hard required by modern } \\
\text { ICT }\end{array}$ & 1.90 & $2.00^{*}$ & $2.23^{*}$ \\
\hline $\begin{array}{l}\text { Lack of communication infrastructure on } \\
\text { which ICTs depend on }\end{array}$ & $2.00^{*}$ & $2.03^{*}$ & $2.20^{*}$ \\
\hline Fear that things will go wrong in using ICT & 0.78 & 0.62 & 1.37 \\
\hline $\begin{array}{l}\text { Inappropriate contents of ICT messages } \\
\text { that do not meet the needs of clients }\end{array}$ & 0.77 & 0.87 & 1.37 \\
\hline Poor benefits in using ICT & 0.70 & 0.85 & 1.63 \\
\hline Lack sufficient trained computer personnel & $2.03^{*}$ & $2.00^{*}$ & $2.20^{*}$ \\
\hline Erratic and fluctuating power supply & $2.55^{\star}$ & $2.38^{*}$ & $2.70^{*}$ \\
\hline Poor finance & $2.32^{*}$ & $2.48^{*}$ & 1.77 \\
\hline Lack of adequate awareness about ICT & 1.90 & $2.28^{*}$ & 1.93 \\
\hline Complexity in using ICT & 1.80 & 1.85 & $2.23^{*}$ \\
\hline Lack of internet access in the rural areas & $2.60^{*}$ & $2.45^{*}$ & $2.00^{*}$ \\
\hline Poor communication network & $2.10^{*}$ & $2.23^{*}$ & 1.80 \\
\hline Nature of information provided & 1.85 & $2.00^{*}$ & $2.43^{*}$ \\
\hline High cost of ICT soft ware & $2.00^{*}$ & $2.72^{*}$ & $2.43^{*}$ \\
\hline High cost of ICT hard ware & $2.08^{*}$ & $2.30^{*}$ & $2.43^{*}$ \\
\hline Negative attitude of people to change & 1.88 & 1.55 & 1.30 \\
\hline $\begin{array}{l}\text { General lack of awareness of the } \\
\text { importance of ICT in agriculture }\end{array}$ & 1.90 & 1.70 & 1.73 \\
\hline
\end{tabular}

* Serious Constraints

\section{Implications}

Ghana perhaps appears to be one of the foremost countries to adopt ICTs in its National Agricultural Research System (NARS) in the West African sub region. Researchers in the Ghanaian NARS are using computer and internet - based ICT to communicate with each other and to carry out some important aspects of their research activities (Sraku - lartey and San, 2003). It is suggested that by 2010, ICT in 
Ghana will be used to conduct researches. According to Global Watch (2002) it will be used in extension activities through the establishment of information centres and telecentres and will facilitate collaborative research through the use of local area networks, wide area networks and research networks due to more inter disciplinary research.

However, in Nigeria, weak and inadequate legal framework on the use of ICTs in extension service has slowed down the agricultural development process. It thus becomes important to understand the specific actors who play (or should play) a role in establishing basic ICTs services in rural areas. Identifying the actors can help orient projects and programmes that would lead them to effectively and collectively engage in dialogue around telecommunications policy reform. These actors according to Richardson (2003) include:

1. Telecommunications service providers (also known as operators)

2. Regulators and policy-makers

3. Telecommunications policy reform advocates (most often found in, and focused on, urban service issues, and sometimes nascent in rural areas)

4. Rural clients (current and potential)

5. 'Last mile' entrepreneurs - phone shop operators and cyber café / telecentre operators

6. Extension managers and other professionals who deliver rural services.

There are many uses for ICTs for facilitating communication, information and advocacy services in the context of improving rural livelihoods, however connectivity constraints in rural areas is still an enormous barrier to the uptake of even basic ICTs. In that regard, extension has an important role to play in facilitating and brokering the participation of rural and agricultural organizations in policy dialogue on telecommunications reform in order to shape national telecommunications policies and programmes to meet the needs of rural areas (Richardson, 2003). This is a very new role for extension. In this role, they must be able to examine the appropriateness of various ICTs, the accessibility of ICTs in rural and remote areas, how best to reconcile costs and benefits, and how to insure that ICTs access include a diversity of cultures, languages, social strata, and age groups, and is gender sensitive (Richardson, 2003).

In conclusion, if modern ICT facilities are not adequately built into the mainstream of Nigerian agricultural extension system, there is likely to be stagnation in the dissemination, utilization and application of scientific agricultural information for purposeful development of the system. Presently in Nigeria, agricultural extension professionals are often absent from national policy dialogues that help create and/or shape positive policy change towards universal ICTs access. If they are not part of national policy dialogue, universal access policies, programmes and regulatory reform initiatives risk neglecting the needs of the very people the initiatives are meant to serve. Information Communication Technologies access implies not only the physical availability of communication equipment and methods but also the existence of the right conditions for their use in getting information. These conditions include the ease of use of the technologies, regular electric power supply and availability of spare parts. In this regard, government should take steps to build three basic infrastructures in the rural areas: electricity, telephone and internet connectivity. 
Journal of Agricultural Extension

Vol. 12 (1) June, 2008

\section{References}

Agwu, A. E. and Chah, J. M. (2007) Access and utilization of modern information communication technologies among extension personnel in Benue State of Nigeria. In: Madukwe, M. C (Ed.). Agricultural Extension and the Challenges of the Millennium Development Goals (MDGs). Proceedings of the $12^{\text {th }}$ Annual Conference of the Agricultural Extension Society of Nigeria (AESON). Maiduguri, $4^{\text {th }}-7^{\text {th }}$ July 2007 . Pp.

Arokoyo, T. (2003) ICTs in the transformation of agricultural extension: The case of Nigeria. Paper presented at the $6^{\text {th }}$ consultative expert meeting of CTA's Observatory on ICTs, Wageningen, September $23^{\text {rd }}-25^{\text {th }}$.

Arokoyo, T. Chikwendu, D. and Ogunbameru, K. (2002). A study of the Access of rural women to public and private extension services in Nigeria. Report by the study commissioned and funded by CTA.

Bertolini, R. (2004) Making Information and Communication Technologies work for Food Security in Africa. International Food Policy Research Institute's (IFPRI) 2020 African Conference Brief 11 pp1-6. www.ifpri.org

CTA (2000). CTA Annual Report. CTA, The Netherlands

CTA (2001) Briefing ICTs in Africa: CTA observatory WICC/CTA,. Wageningen. The Netherlands. London: Sage publishing.

CTA (2003). CTS - Transforming agricultural extension. CTA observatory WICC/CTA, Wageningen, The Netherlands.

Global Watch on line. (2002). Canadian Biotechpoised for Boom, Retrieved from http:// www.global watchonline. Com/magazine/gw pdfs/Gw issue:17.

Greenidge, C. B. (2003). ICTs and the rural sector in ACP State: Mirage or Marriage? Address delivered at the CTA's ICT observatory U.S.A.

Lightfoot, C (2003) Demand -driven extension : some challenges for policy makers and managers. ICTs - Transforming Agricultural Extension? The $6^{\text {th }}$ Consultative Expert Meeting of CTA's Observatory on ICTs, Wageningen, 2325 September, 2003.

Meera, S.N., Jhamtani, A.; and Rao D.U.M (2004). Information and communication technology in agricultural development: A comparative analysis of three projects from India. AgREN Agricultural Research and Extension Network No. 135.

Michiels, S and Van Crowder, L. (2001). Discovering the Magic Box Local Appropriation of Information and Communication Technologies (ICTs) FAO, Rome. http://www.fao.org/sd/2001/KN060 2a_en.htm

Richardson, D. (2003) Agricultural extension transforming ICTs. Championing universal access. In CTA ICTs - Transforming Agricultural Extension? The $6^{\text {th }}$ Consultative Expert Meeting of CTA's Observatory on ICTs, Wageningen, 2325 September, 2003.

Seepersad. J. (2003). Case study in ICTs in Agricultural Extension in Trinidad and Tobago. In CTA ICTs - Transforming Agricultural Extension? The $6^{\text {th }}$ Consultative Expert Meeting of CTA's Observatory on ICTs, Wageningen, 2325 September, 2003. 
Shaib, B., Aliyu, A. and Bakshi, J.S (eds.) (1997) Nigeria: National Agricultural Research Strategy Plan 1996-2010. Federal Department of Agricultural Sciences, Federal Ministry of Agriculture and National Resources, Abuja, Nigeria.

Sraku - Lartey, M and Sam, J. (2003). ICTs and national agricultural research system: The case of Ghana. Information Division forestry research Institute of Ghana publication.

The Academy for Educational Development and Win rock International (2003). Future directions in agriculture and information and communication technology (ICTs) at USAID. Version 4.

UNDP (2001) Information Communications Technology for Development. Essentials ICTD 31. Synthesis of Lessons Learned. Evaluation Office N0. 5 September. New York. http://www.undp.org/eo

Yekinni, O. T. and Olaniyi, O. A. (2007) Analysis of e-readiness of agricultural development practitioners to emerging information challenges: A case study of researchers and extension personnel in South-western Nigeria. Journal of Agricultural Extension. Vol. 10 pp. 27-39. 